\title{
Influencing the crystallization of secondary alloy AISi6Cu4 with strontium
}

Dana Bolibruchová, Marek Brůna

University of Žilina,Faculty of Mechnical Engineering, Department of technological engineering, Univerzitná 1, Žilina, Slovakia.danka.bolibruchova@fstroj.uniza.sk,marek.bruna@fstroj.uniza.sk

This work deals with modification of aluminum alloy AlSi6Cu4 with strontium in graduated amounts. Submited article examines modification influence on the mechanical properties such as tensile strength (Rm), elongation (A5) and Brinell hardness (HBW). Article also includes analysis of alloy microstructure modified by strontium and analyzes the impact of strontium on the gas content of the melt. This work deals with finding the optimal amount of strontium to achieve changes in the shape of the coarse eutectic silicon plates to fine rounded AlSi6Cu4 alloy rods. Durin experiment was found, that optimum amount of the used modifier with respect to the mechanical properties of the surveyed sample is 2000 ppm AISr5. But with the increasing amount of modifier in the alloy decreases fludity.

Keyword: AlSi6Cu4 Alloy, modification, strontium, mechanical properties, microstructure

\section{Acknowledgements}

This work was created within the solution of the grant project VEGA no 1/0363/13. The authors thank to Grant Agency for support.

\section{References}

[1] MAgÁTOVÁ M. (2012) Diploma thesis, pp. 57.

[2] BOLIBRUCHOVÁ, D., Pastirčák, R., SLÁDEK, A. (2005). Foundry metallurgy- non-ferrous metals with instructions for exercises. Žilina: 1 ed. EDIS, pp. 172, ISBN 80-8070-457-0.

[3] BOLIBRUChOVÁ, D. - Tillová, E. (2005) Foundry Al-Si alloys. Žilina: 1 ed. EDIS, pp. 180, ISBN 808070-485-5.

[4] CASTRO-ROMAN, M. et al. (2006) Strontium Effect on the Solidification Path of a 319 - Type Aluminium. USA: Publisher. American Foundrymen's Society Illinois

[5] DAHLE A. K., NOGITA, K., McDONALD, S. D. (2005) Eutektic modification and microstructure development in Al-Si Alloys. Brisbane: The University of Queensland, pp. 243-248. 0921-5093.

[6] GRUZLESKI J. E., ClOSSET, B. M. (1990) The Treatment of Liquid Aluminium - Silicon Alloys. USA: Publisher. American Foundrymen's Society of Illinois, pp. 256.

[7] MICHNA, Š. et al. (2005) Encyclopedia of aluminum. Prešov: 1. ed. Edin, 720 p. ISBN80-89041-88-4.

[8] MUlaZimoglu, N., TENEKEDJEV, N., GLOSSET. B. (1995). Commercial and Microstructures of Al Alloy With $319 \mathrm{Mg}$ and Sr Additions. Canada: The University of Quebec - Chicoutimi, 15 p. 951-962.

[9] SAMUEL F. H., OUELLET, P. (1997) Microstructural Interpretation of Thermal Analysis of Commercial 319 Al Alloy With Mg and Sr Additions. Canada: The University of Quebec - Chicoutimi, 15 p. 951-962.

[10] TENEKEDJIEV et al. (1995) Microstructures Thermal Analysis of Strontium - Treated Aluminium-Silicon Alloys. USA: Publisher. American Foundrymen's Society Illinois, pp. 79.

[11] TILlOVÁ, E., CHALUPOVÁ, M. (2009) Structural analysis of Al-Si alloys. Zilina: EDIS, pp. 191, ISBN 97880-554-0088-4.

[12] PASTIRČÁK, R., URGELA, D., KRIVOŠ, E.: Production of casting by patternless process. In: Archives of foundry engineering. ISSN 1897-3310. Vol. 12, issue 1, (2012), s. 87-92.

[13] MICHNA, Š. - NÁPRSTKOVÁ, N.: Research into the causes cracking of aluminium alloys of $\mathrm{Al}-\mathrm{Cu}$ during mechanical machining. In: Manufacturing Technology, volume 12, 2012, ISSN 1213-2489. 